\title{
CHANGES IN PENSION INEQUALITY: A DECOMPOSITION ANALYSIS OF ARGENTINA, 1995-2009*
}

\section{VANESA VALERIA D'Elia**}

\begin{abstract}
We use microdata from the National Social Security Administration to document pension inequality in Argentina between 1995 and 2009 and perform decomposition techniques to analyze the relationship between pension reforms and observed inequality. We find that before 2003, pensions under SIJP rules, the incorporation of provincial benefits into the national scheme and the increase of female retirees play important roles in accounting for increased inequality, while after 2003 the increase in the share of minimum pensions and implementation of the moratorium program appear to be the most significant factors in explaining more equal distribution.
\end{abstract}

JEL classification: D31, H55

Keywords: pension, inequality, decomposition, Argentina

\section{INTRODUCTION}

During the 1990s, a wave of structural reforms were implemented that changed the distributional principles underpinning public policy in Argentina. One of the results of the process of deregulation, privatization and reduction of the role of the state in the economic sphere was a new design for the country's pension system that featured capitalization and pay-as-you-go (PAYG) components. Following this reform, the main performance indicators of the pension system (such as pension coverage and replacement rate) showed a continuous deterioration in line with certain labor market indicators. Since 2003, with a new national government, several regulatory adjustments have been made and in 2008 the pension system was completely reformed, becoming a public PAYG scheme once again.

All of these reforms have brought about changes in inequalities which affect the elderly. Although there have been many empirical analyses of income distribution in Argentina in recent decades (see, for example,

\footnotetext{
* I thank Roque Fernández, Julio Elías and Mariana Conte Grand from the Universidad del CEMA and Leonardo Gasparini form the Universidad Nacional de la Plata for their useful comments. The views and opinions expressed in this publication are those of the author and are not necessarily those of the Administración Nacional de la Seguridad Social (ANSES).

** Social Security Studies Department, Administración Nacional de la Seguridad Social (ANSES), Av. Córdoba 720, 1st floor, Buenos Aires (C1054AAT), Argentina. Tel: +54-11-4015-1497.
} 
Cruces and Gasparini, 2009 and Groisman, 2008), empirical literature focusing exclusively on the distributional aspects of the Argentinean pension system is scarce.

By definition, a pension formula implies a transfer of income from the period during which a person works to their retirement period. As the public system in Argentina is a PAYG system, there is also an income transfer from current workers to current pensioners, because benefits are funded directly by current workers' contributions and taxes. In this case, the analysis of pension distribution has typically been approached from two perspectives: the intergenerational dimension (i.e., distribution analysis across generations), and the intra-generational dimension (i.e., distribution within the same generation). For example, using a lifetime income approach, Rofman (1995) concluded that older workers will receive better returns from the pension system (either public or private) than younger workers. Arza (2006) estimated the internal rates of return (IRRs) for different birth cohorts of workers, and concludes that earlier generations of workers benefited from higher pension IRRs than later generations. ${ }^{1}$ Regarding intra-generational income transfers, Arza concludes that there has been some progressive redistribution among the covered elderly population, but this impact could be offset by unequal coverage (those who do not benefit from the system pay some costs via taxes). ${ }^{2}$ In another line of analysis, Giuri and Martinez (2001) evaluated pension inequality in Argentina between 1992 and 2000 and concluded that inequality increased over that period, with the transfer of some provincial pension systems to the national system explaining that increase. They also found that subsidies and family allowances granted to the poorest retirees reduced inequality.

This article focuses on the distributional impacts of recent reforms on the pension system. More precisely, this study: i) documents pension inequality between 1995 and 2009, ii) briefly describes the legislative pension reforms implemented during that period and 3) analyzes the relationship between the reforms and the observed inequality using Theil decomposition techniques and a micro-econometric approach.

The rest of the paper is organized as follows: Section 2 examines pension data from the National Social Security Administration (Administración

1. The IRR is defined as "...the rate at which total social security contributions paid over the lifetime equal the present value of the expected stream of benefits received after retirement" (Arza, 2006: 84).

2. For the distributional impacts of unequal coverage, see also Arza (2008). 
Nacional de la Seguridad Social, or ANSES) to evaluate the stylized facts explored in this study. It also includes a brief description of the main pension system reforms since 1993. Section 3 describes the methodology and data used to analyze the relationship between the reforms and changes in pension inequality, while the results are presented in Section 4. Finally, Section 5 presents concluding remarks and suggests some issues to guide future research.

\section{Changes IN INEQUALITY: BASIC FACTS}

Using unpublished data from the National Social Security Administration (ANSES), empirical evidence shows that pension inequality fell between 1993 and 2009. However, this decrease in inequality was not uniform throughout the period. As can be seen in Table 1, the Gini index increased slightly in the 1993-1997 period. From 1998 to 2002, the index remained relatively stable, and in the following years, starting in 2003, the distribution changed substantially, becoming more equal until 2008. In fact, 2008 appears to be the most egalitarian point in the entire period, while in 2009 inequality increased. This behavior is echoed in the other measurements considered. In 1993, the average pension of the highest decile represented about 6.5 times the average pension of the lowest decile while in 2003 this ratio increased to 9.4 times. However in 2009 it decreased to almost 3.4. The last column of Table 1 shows the evolution of the labor income Gini coefficient. As can be seen, both pension and income distribution present very similar patterns, but the decline in the income index from 2003 to 2008 was smoother than the decrease in the pension index. Moreover, while the income Gini index remained relatively stable in 2008 and 2009 , it showed an increase in inequality for the pension sector.

Figure 1 shows the median and the 1st and 10th deciles of the real pension distribution for the 1993-2009 period. Given the availability of the data, the average pension in April of each year was considered to be representative of the annual average. The information from 1994 is not taken into account because of consistency issues. Average pensions are indexed to 100 in 1993 for all three series.

Until 2001, pensions in the 1st decile and the median pension remained relatively stable, while pensions in the highest decile increased by $52 \%$ in real terms (with a $31 \%$ increase in 1997). Due to the economic crisis of 2001 and devaluation of the Argentine peso (the official exchange rate increased from 1 to 1.4 pesos per U.S. dollar), real pensions 


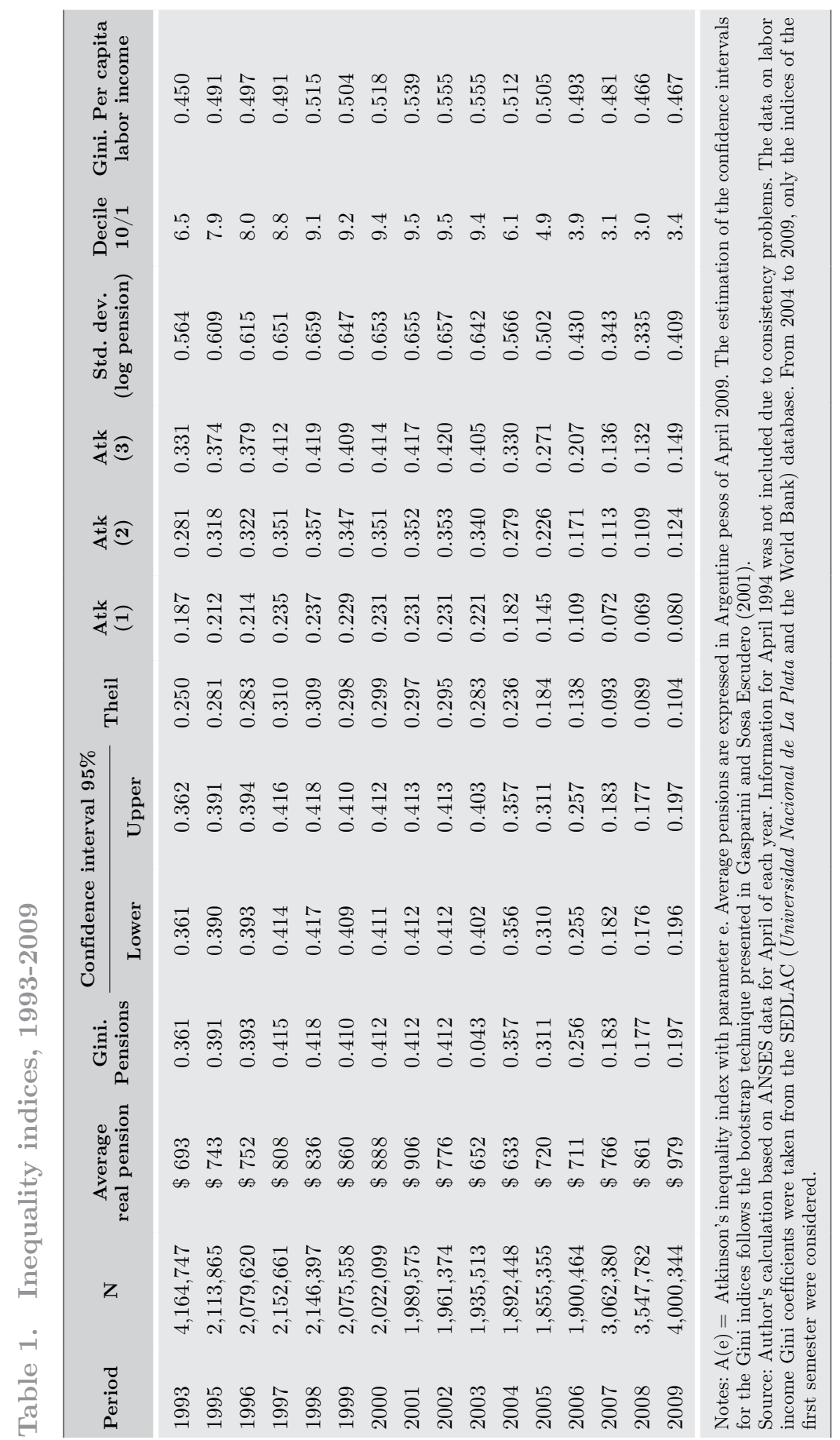


Figure 1. Indexed real pensions by decile, 1993-2009

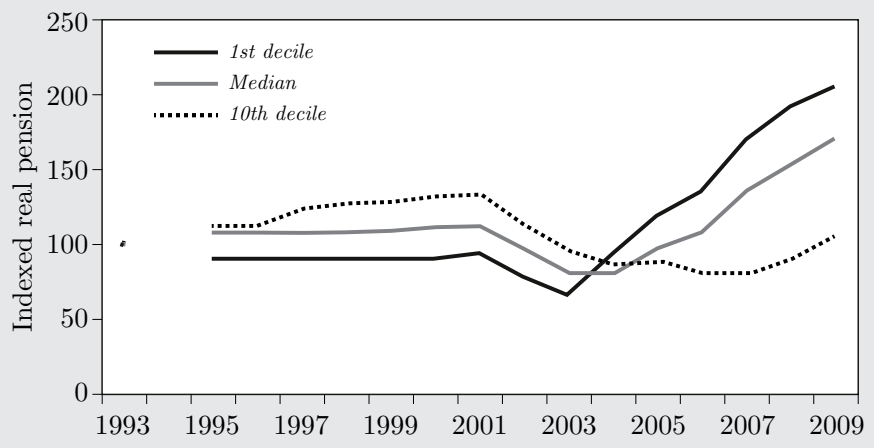

Source: Author's calculation based on ANSES data for April of each year.

fell almost $30 \%$ in all three groups until $2003 .{ }^{3}$ From 2003 to 2009 , pensions in the bottom $10 \%$ and the median pension increased steadily (208\% for the former and $106 \%$ for the latter). In contrast, pensions in the top $10 \%$ of the distribution declined $17 \%$ during the 2003-2007 period, and then rose more than $30 \%$ in the next two years. By the end of the period, all groups had exceeded the 2001 values, but there were significant differences in pension evolution among the different groups. This means that pension inequality changed starting in 2003, with inequality declining from 2003 to 2009.

Taking into account the abovementioned results, Figure 2 below decomposes the changes in pensions by decile in four sub-periods.

The first period extends from 1993 to 2003 (Panel A), the second period is from 2003 to 2007 (Panel B), and the third one extends from 2007 to 2009 (Panel C). In all cases, the pension changes per decile are normalized using the mean log pensions over each period. Finally, Panel D shows the pension distribution for the 2003-2009 period.

As shown in Figure 2, from 1993 to 2003 pensioners in or below the first pension distribution decile lost about $6 \%$ relative to the average, 
Figure 2. Change in log relative pension by decile, 1993-2009

\section{A. 1993-2003}

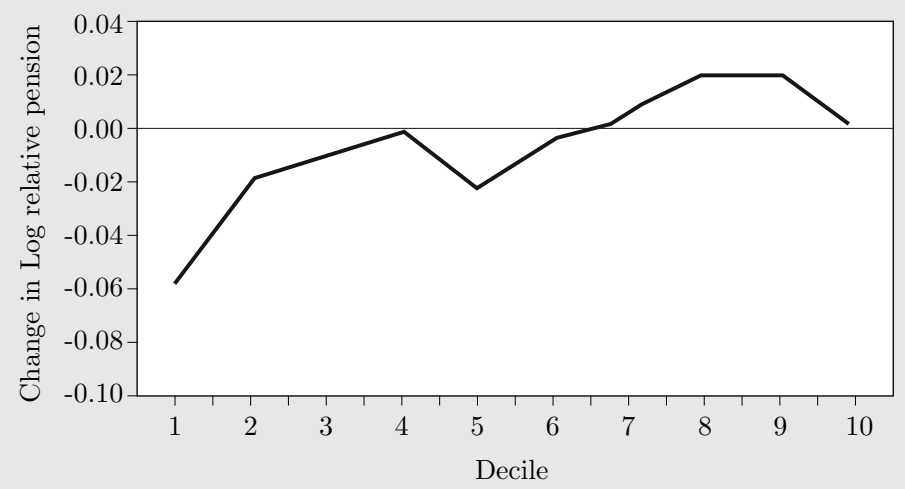

B. 2003-2007

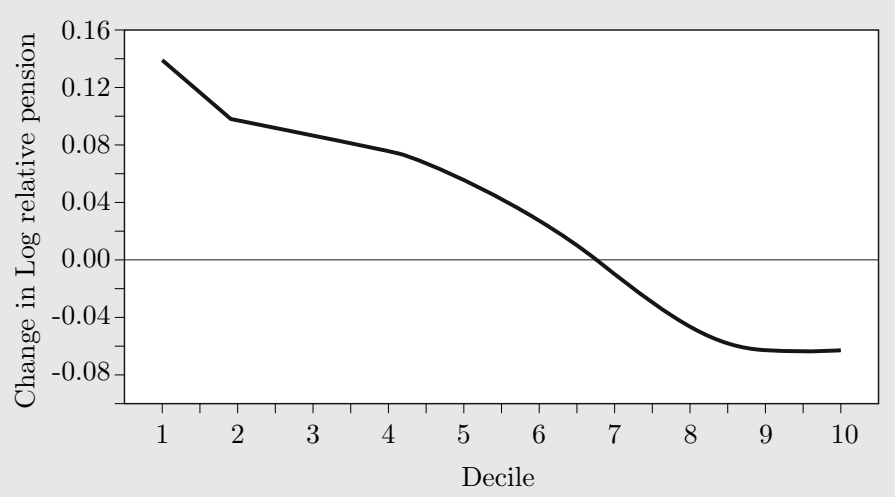

while pensioners in the highest deciles gained between $0.1 \%$ and $2 \%$ in relation to the average pension.

The changes during the 2003-2007 period are totally contrary. As can be seen in Panel B, pensioners in the lowest decile gained about $14 \%$ relative to the mean, while pensioners in the highest deciles lost more than $6 \%$. The increase in pensions over the period is roughly a linear function (with a negative slope) of the deciles. Panel $\mathrm{C}$ shows that the change in inequality was quite modest over the last period (2007-2009). Pensioners in the lowest decile lost approximately $0.7 \%$ in relation to the mean pensioner, and pensioners in the upper deciles 
Figure 2. (continued)

A. 2007-2009

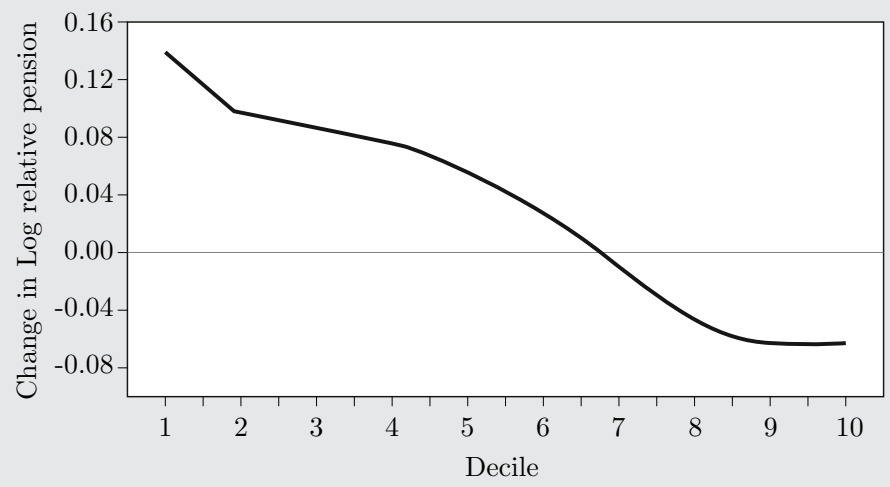

B. 2003-2009

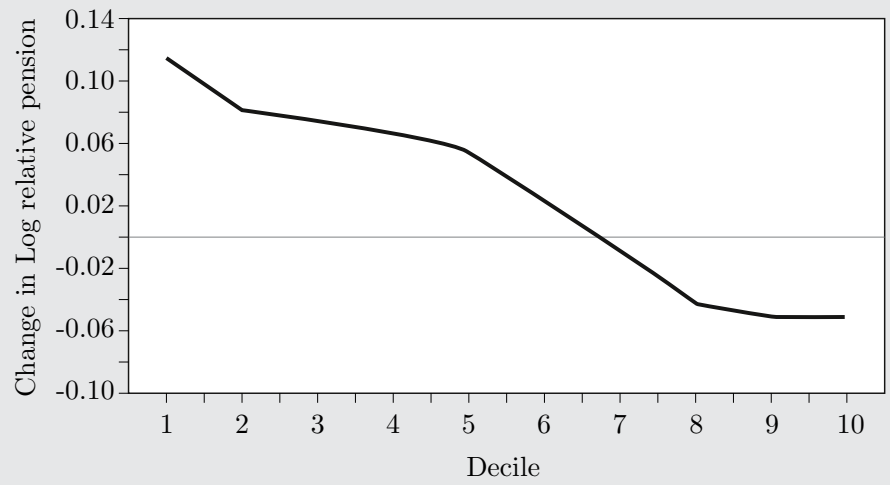

Source: Author's calculation based on ANSES data for April of each year.

gained about $0.1 \%$ in comparison to the mean pensioner. Finally, the distribution pattern of Panel D is very similar to that in Panel B, because pension dispersion has barely changed in the last few years.

The overall conclusion is that pension inequality changed over the entire period, and that the direction and magnitude of the change depended on the period considered. In this sense, two periods of analysis can be distinguished: 1993 to 2003 and 2003 to 2009 .

Figure 3 shows the evolution of inequality (Theil index), together with the main pension system reforms in 1993-2009. 
Figure 3. Theil index and pension reforms, 1993-2009

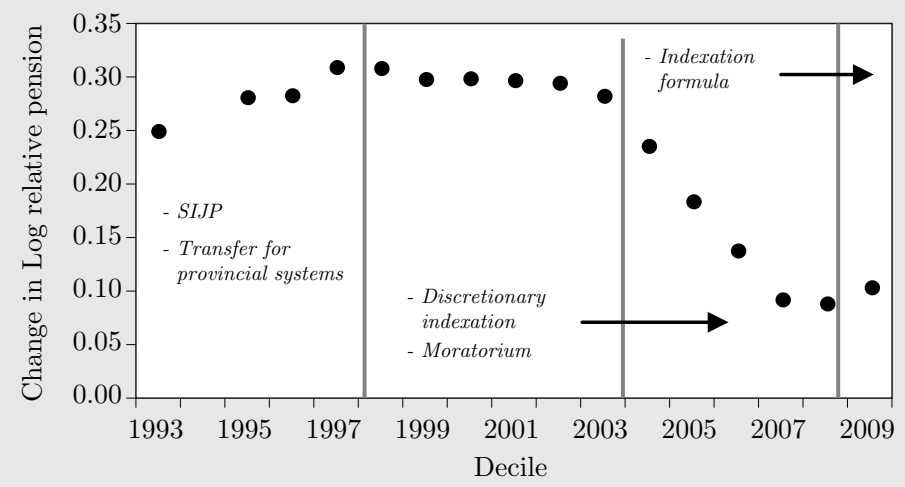

Source: Author's calculations based on ANSES data for April of each year.

As can be seen, the evolution of pension inequality over the whole period is consistent with the implementation of the most extensive reforms to Argentina's pension system during that period. The main characteristics of such reforms are presented below.

\subsection{Pension system reforms from 1993 to 2009}

\section{Creation of the SIJP}

In 1993, in response to the serious financial problems faced by Argentina's pension system, a new system known as the Integrated Retirement and Pension System (Sistema Integrado de Jubilaciones y Pensiones, or SIJP) was approved, and it came into force in July 1994 (SSSa, 2003). The design of the new scheme was largely based on ideas published in the World Bank's 1994 report Averting the Old Age Crisis (see Arza, 2008). With this reform, Argentina's social security system became a mixed scheme on the one hand, a government-run pay-asyou-go (PAYG) system continued to exist (as it had since 1954), and in addition, a fully funded, privately managed scheme was created. ${ }^{4}$ Until this reform, benefits comprised between $70 \%$ and $82 \%$ of the pensioner's salary during the three highest-earning years in the 10

4. At that time, each worker had to choose a system. Those who decided to enter the private system do not have the option of returning to the public scheme, although workers in the PAYG system could change to the private regime. 
years before retirement. A minimum of 10 years of contributions were required, and it was stipulated that this requirement would increase over the next years up to a maximum of 30 years.

With the new design, the pension system became a multi-pillar scheme combining defined-benefit and defined-contribution components. ${ }^{5}$ Pension entitlement was made up of the sum of three independent benefits: a flat-rate benefit (prestación básica universal, or PBU), an earning-related pillar that recognizes contributions made before the reform (prestación compensatoria, or PC), and an additional earningsrelated pillar for contributions made after July 1994, paid either by the public system if the worker remained in the PAYG regime, or the insurance company if the worker was affiliated with the private system. This third pillar was known as the prestación adicional por permanencia (PAP) in the first case, and jubilación ordinaria (JO) in the second. Like the PC, the PAP was defined as a percentage of the worker's salary, while the JO was calculated as an actuarial annuity (see Table A1 of the appendix). ${ }^{6}$

Apart from the change in the benefit formula and the vesting period, the retirement age has been increased from 55 to 60 for women and from 60 to 65 for men. This change has been implemented progressively (over a 15-year period after the reform) in order to avoid abrupt impacts on workers close to retirement.

\section{Transfer of provincial pensions to the national sphere}

In August 1993, the national government and the provinces signed Fiscal Agreement II (Pacto Federal para el Empleo, la Producción y el Crecimiento), wherein the national government committed to incorporating provincial pensions into the national system. Prior to the reform, each province maintained a separate pension fund for employees and benefit payments were funded out of current revenues. These included, in addition to earmarked salary deductions, subsidies from general treasury revenues.

\footnotetext{
5. A defined benefit plan guarantees a certain payout upon retirement, according to a fixed formula that usually includes the member's salary and the number of years of membership in the pension system. A defined contribution plan provides a payout upon retirement that depends on the amount of money contributed and performance of the investment vehicles utilized (World Bank, 1994).

6. From 1994 to 2007 the PC was calculated as $1.5 \%$ of the worker's salary per year of contribution, and the PAP was defined as $0.85 \%$ of the worker's salary per year of contribution. In 2007 , the PAP percentage was increased to $1.5 \%$.
} 
Under Fiscal Agreement II, the federal government agreed to take over the pension system of every province that passed a law authorizing it to do so. After the transfer, the federal pension system would eventually confer on federal and provincial civil servants the same retirement eligibility conditions, contributions, and benefits that were available to the private sector.

Since the 1994 reform, 12 jurisdictions have been transferred to the national scheme (the most recent province system was transferred in 1997). ${ }^{7}$ Benefits from these schemes were generally $82 \%$ of the worker's mean salary, and therefore pensions in this group were higher than those in the national scheme.

\section{Coverage and the moratorium scheme}

One important performance indicator of a pension system is its coverage. The proportion of elderly people (aged 65 or more) with a pension benefit decreased in the aftermath of the 1993 reform: In 1994, in a context of growing unemployment and informality, there were 77 beneficiaries for every 100 elderly people in Argentina, and by 2003 this number had dropped to 68 (Rofman et al., 2008). If only retirees participating in the national system are considered, the coverage is estimated to have been $57 \%$ in 2003 and $55 \%$ in 2005 .

To regularize the social security debts of independent workers, a program referred to as a moratorium was approved in 1995. Under Law 24,476, self-employed workers were allowed to pay contributions they owed to the system prior to September 1993 in installments. ${ }^{8}$ But this law failed to improve pension coverage. In January 2004, Law 25,865 allowed selfemployed people of minimum retirement age or older to apply to receive a pension by paying the contributions owed to satisfy the required contribution time period (there was no restriction regarding the period that could be regularized). This law expired in 2005 .

But the main program of the moratorium scheme was passed in December 2004 with Law 25,994, the Retirement Inclusion Plan (Plan de Inclusión Previsional), which allowed people of retirement age with

7. To date, the jurisdictions that have subscribed to the SIJP are: Municipality of Buenos Aires (1994), the provinces of Santiago del Estero (1994), Catamarca (1994), Salta (1996), Mendoza (1996), San Juan (1996), La Rioja (1996), Río Negro (1996), Jujuy (1996), Tucumán (1996), San Luis (1996) and the Municipality of Tucumán (1997).

8. Decree $1454 / 2005$ allows the contributions owed to be discounted from pensions. 
insufficient contributions to receive a pension after paying their debt to the system. It also allowed individuals who met the minimum contribution time requirement but not the minimum age (up to five years younger than required), to apply for a pension benefit. The program, which was in effect until April 2007, increased the number of new beneficiaries under the law by around 2.1 million by 2010, with women accounting for more than $80 \%$ of new beneficiaries. Since the implementation of the plan, coverage has expanded, and by 2010 the proportion of the elderly receiving a national pension was almost $88 \%$ (D'Elia, et al., 2010).

\section{Special pension schemes}

Until 1994, there were special pension schemes for teachers, scientific researchers, diplomats and judiciary employees. Workers affiliated with these schemes obtained a pension with a replacement rate that ranged from $82 \%$ to $85 \%$ of the last monthly remuneration received. Unlike other schemes, in the special pension programs neither the remuneration subject to contributions nor the pensions were capped. Contributions in some of these schemes were increased by two percentage points (i.e., instead of $11 \%$, participants contributed $13 \%$ of their salary). ${ }^{9}$ While Decree 78/1994 phased out the special pension schemes starting in 2001, these programs were gradually restored and by 2007 all were operating again. ${ }^{10}$

\section{Pension indexation}

From 1994 until the 2001 crisis, the minimum pension amount remained stable in both real and nominal terms (ARS 150). With the devaluation of the Argentine peso and the resulting inflationary situation, minimum benefits declined around $20 \%$ in real terms in 2002 . In order to restore retirees' purchasing power, pensions were adjusted discretionally during 2003-2008. Minimum pensions increased $360 \%$ in nominal terms and $195 \%$ in real terms using the consumer price index compiled by the National Institute of Statistics and Censuses (Instituto Nacional de Estadística y Censos, or INDEC) as a deflator. The average pension,

9. See Decree $160 / 2005$.

10. For further details on these programs, see Law 24,016 and Law 26,508 (for teachers in public primary and secondary schools and public universities, respectively), Law 22,929 (for scientific researchers), Law 22,731 (for diplomats), and Law 24,018 for judiciary employees. 
however, increased less than the minimum: $142 \%$ in nominal terms and $56 \%$ in real terms over the period. ${ }^{11}$

In October 2008, an automatic formula for pension indexation was approved with Law 26,417. The formula took into account the evolution of the financial resources of the pension system, the evolution of salaries and the number of pensions. ${ }^{12}$ Under this formula, all pensions are adjusted twice a year (in March and September), with the first adjustment occurring in March 2009. ${ }^{13}$

\section{The creation of SIPA}

In November 2008, a new reform was approved with Law 26,425, which created the Argentinean Integrated Pension System (Sistema Integrado Previsional Argentino, or SIPA). The private, fully funded scheme was eliminated and the entire pension system became a PAYG scheme again. Workers affiliated with the private system were transferred to the national program together with the funds accumulated in their individual accounts. ${ }^{14}$ More than 9.7 million contributors to private pensions (administradoras de fondos de jubilaciones y pensiones, or AFJPs, representing $60 \%$ of total affiliates) were switched to the public system (AFIP, 2008) and almost 380,000 private pensions were transferred to the national scheme (with the exception of beneficiaries receiving their pensions through a life annuity). The Guarantee and Sustainability Fund (Fondo de Garantia de Sustentabilidad, or FGS) received the stock accumulated in the individual accounts, which was worth ARS 80.2 billion in December 2008 (ANSES, 2009).

11. Using an alternative price index constructed as an average of the official indices of seven agglomerations in Argentina (Jujuy, Neuquén, Paraná, Rawson-Trelew, Salta, Santa Rosa and Viedma), the minimum and average pension increased $128 \%$ and $20 \%$ respectively.

12. The indexation formula is defined as $m=\left\{\begin{array}{ll}a=0.5 \cdot R T+0.5 \cdot w & \text { if } \mathrm{a} \leq \mathrm{b} \\ b=1.03 \cdot r & \text { if } \mathrm{a}>\mathrm{b}\end{array}\right.$ where $m$ is the index,

$R T$ is the semiannual change in per benefit tax resources that finance the national pension system, $w$ is the semiannual change in salaries and $r$ is the annual change in per benefit total resources of ANSES.

13. Benefits under some schemes (such as those for academic researchers, school and university teachers, diplomats, energy workers, etc.) have indexation coefficients different from that of Law 26,417. However, such benefits represent only $3 \%$ of total benefits.

14. Previously, Law 26,222 of 2007 established the possibility of switching contributors from the funded to the PAYG scheme. More than 2.6 million workers moved to the public system (21\% of total affiliates at that time): $49 \%$ of the transfers were voluntary and the rest were compulsory (workers covered by special schemes and workers with less than ARS 20,000 in their accounts (AFIP, 2008)). The funds accumulated in the individual pension accounts were transferred to the Guarantee and Sustainability Fund (FGS) created in 2007 by Decree 897 and managed by ANSES. 
Each reform divides the population of pensioners into mutually exclusive groups, such as pensioners who access a benefit through a moratorium versus non-moratorium pensioners and pensioners who belong to a special scheme versus pensioners who belong to a general scheme. If these reforms are related to observed changes in pension differentials, it is possible to analyze the effects that each episode of reform could separately have on pension distribution. In this sense, examining inequalities between the pensions of different groups defined by the reforms above results in a pioneering and valuable approach to analysis of the factors that could determine pension distribution. The section below presents the methodology used to characterize both the level of pension inequality and changes to that level in light of the most significant reforms.

\section{METHODOLOGY AND DATA}

Decomposability of inequality measures involves dividing the target population into groups, considering relevant factors that potentially account for income inequality. In the context of additive decomposability, the total inequality index can be decomposed into two elements: within inequality and between inequality. The "within" inequality element captures inequality due to income variability within each group, while the "between" inequality element captures inequality due to income variability across different groups.

One measure that is perfectly decomposable in the "within" and "between" elements is the Theil index. ${ }^{15}$ Assuming $j$ groups, its decomposition adopts the following form:

$$
T=\underbrace{\sum_{j}\left(\frac{N_{j} \cdot \mu_{j}}{N \cdot \mu}\right) \cdot T_{j}}_{\text {within }}+\underbrace{\sum_{j}\left(\frac{N_{j} \cdot \mu_{j}}{N \cdot \mu}\right) \cdot \ln \left(\frac{\mu_{j}}{\mu}\right)}_{\text {between }}
$$

The first term is the weighted average of the Theil inequality indices of each group $(T j)$, with weights represented by total income share. This is the "within" part of the decomposition (not explained by the factors chosen).

15. There are several decomposable inequality indicators. In practice, the most convenient one for the decomposition is the family of generalized entropy indices including the mean logarithmic deviation, the Theil coefficient, and half of the squared coefficient of variation (for further details, see Bourguignon, 1979, Shorrocks, 1984, and Cowell, 1980). For an empirical analysis of income distribution in Argentina using the Theil decomposition, see Gasparini (1999) and for an empirical study of pension distribution see Giuri and Martinez (2001). 
The second term is the Theil index calculated using subgroup means instead of actual incomes. This follows the logic of replacing actual income distributions in each group with the average income level of the same group. This yields the "between" part of the decomposition.

The inequality "accounted for" by the decomposition is the "between" element, while the "within" element identifies the contribution to inequality of the variability of each group income taken separately.

It is also worth identifying the components of the change in inequality between different points in time. A recent stream of decomposition methodologies is based on a parametric representation of the way in which individual income is linked to individual socio-demographic characteristics. Changes in inequality could arise from changes in the distributions of observable covariates, the observable return of those characteristics, and changes in the dispersion of unobservables. In this sense, the microeconometric decomposition technique proposed by Juhn, Murphy and Pierce (1993, referred to hereafter as JMP) results in a useful framework for exploring the extent to which the different factors that determine changes in inequality explain observed changes in pension distribution. ${ }^{16}$

Following JMP closely, it is possible to decompose the total inequality change into three effects: changes in observed characteristics, changes in observed prices, and changes in unobserved prices and characteristics.

To perform the decomposition, we consider two periods of analysis: the first is 1996 to 2003 and second is from 2006 to 2009. ${ }^{17}$ Delimitation of these periods has to do with the availability of data (pensioners' gender details are available from 1996) and with the fact that because the moratorium program and special regime schemes were not fully implemented until 2006, it was not possible to decompose the change prior to that year and capture the contributions of these policies on inequality change after 2003.

First, we estimate a simple pension model:

$$
Y_{i t}=\alpha_{t}+\sum_{k=1}^{K} \beta_{k t} X_{i t}+\mu_{i t}
$$

16. In addition to the methodology proposed by JMP, other examples of these microeconometric methods are the pioneering Oaxaca-Blinder decomposition of differences in mean incomes across population groups with different characteristics (Blinder, 1993; Oaxaca, 1993) and Bourguignon, Ferreira and Lustig (2005), and variants of these techniques.

17. As shown in Figure A1 of the appendix, pension distribution became more unequal during the 1996-2003 period and more equal during the 2006-2009 period. 
where $Y_{i t}$ is the vector of $\log$ real pension for individual $i$ in year $t ; X_{i t}$ is a vector of individual characteristics (including gender, national/ provincial nature of the benefit, pre/post-SIJP nature of the benefit in the 1996 and 2003 equations, and adding the moratorium/nonmoratorium and special/general scheme nature of the benefits as explanatory variables in the 2006 and 2009 equations). $\beta_{k t}$ is the vector of estimated coefficients (observable prices), $a_{t}$ is the constant term of the regression of year $t$, and $\mu_{i t}$ is the pension component accounted for by the unobservables. This residual includes all factors other than the independent variables that also determine the pension amount, for example, the unobservable characteristics of the individual that affect pension level.

The residual gap is thought to consist of two components: an individual's percentile in the residual distribution $p_{i t}$ and the distribution function of the pension equation residuals $F_{t}($.$) . Then,$ $p_{i t}=F_{t}\left(\mu_{i t} \mid X_{i t}\right)$ can be considered the percentile of an individual residual in the residual distribution of the model in year $t$. Hence, the percentile represents the probability that another residual chosen randomly may be less than $\mu_{i t}$.

By definition, we can write:

$$
\mu_{i t}=F_{t}^{-1}\left(p_{i t} \mid X_{i t}\right)
$$

where $F_{t}^{-1}\left(. \mid X_{i t}\right)$ is the inverse of the cumulative distribution function for pensions with characteristics $X_{i t}$ in year $t$.

Next, let us assume $\bar{F}_{t}($.$) to be the reference residual distribution$ (e.g., the average residual distribution over both samples, 1996-2003 and 2006-2009), and $\bar{\beta}_{k}$ and $\bar{\alpha}$ an estimate of benchmark coefficients (e.g., the coefficients from a model pooled over the whole sample). Using this framework, we can reconstruct hypothetical outcome distributions with any of the components that remain fixed. We can then determine:

1) hypothetical outcomes with varying quantities between the groups and fixed prices (coefficients) and a fixed residual distribution, such as:

$$
Y_{i t}^{(1)}=\alpha_{t}+\sum_{k=1}^{K} \bar{\beta}_{k} X_{i t}+\bar{F}^{-1}\left(p_{i t} \mid X_{i t}\right)
$$


2) hypothetical outcomes with varying quantities and varying prices, and fixed residual distribution, such as:

$$
Y_{i t}^{(2)}=\alpha_{t}+\sum_{k=1}^{K} \beta_{k t} X_{i t}+\bar{F}^{-1}\left(p_{i t} \mid X_{i t}\right)
$$

3) outcomes with varying quantities, varying prices, and a varying residual distribution, such as:

$$
\begin{aligned}
Y_{i t}^{(3)} & =\alpha_{t}+\sum_{k=1}^{K} \beta_{k t} X_{i t}+F_{t}^{-1}\left(p_{i t} \mid X_{i t}\right) \\
& =\alpha_{t}+\sum_{k=1}^{K} \beta_{k t} X_{i t}+\mu_{i t}=Y_{i t}
\end{aligned}
$$

The differential $Y_{i t}-Y_{i t-1}$ can be decomposed as follows:

$$
\begin{aligned}
\underbrace{Y_{i t}-Y_{i t-1}}_{T} & =\underbrace{\left[Y_{i t}^{(1)}-Y_{i t-1}^{(1)}\right]}_{Q}+\underbrace{\left[\left(Y_{i t}^{(2)}-Y_{i t-1}^{(2)}\right)-\left(Y_{i t}^{(1)}-Y_{i t-1}^{(1)}\right)\right]}_{P} \\
& +\underbrace{\left[\left(Y_{i t}^{(3)}-Y_{i t-1}^{(3)}\right)-\left(Y_{i t}^{(2)}-Y_{i t-1}^{(2)}\right)\right]}_{U}
\end{aligned}
$$

where $T$ is the total difference, $Q$ can be attributed to differences in observable quantities, $P$ to differences in observable prices, and $U$ to differences in unobservable quantities and prices. This last component not only captures the effect of unmeasured prices and the effect of differences in the distribution of unmeasured characteristics (e.g., one of the unmeasured characteristics is more important in year $t$ or $t-1$ for generating pensions), but also the measurement error. The ability to estimate how different parts of the pension distribution have been affected by the various components is the major advantage of the full distribution accounting scheme proposed here.

The data used in this study have been taken from the ANSES and this is one of the most valuable innovations in this analysis: this is the first paper on the Argentinean pension system that uses microdata on the total pensioner population (rather than samples of the ANSES database) and the period covered is substantial (16 
years). ${ }^{18}$ The database contains information about different pensioner characteristics, including the pension amount in April of each year from 1993 to 2009, with the exception of April 1994 (individual data were not available for that year; see Table 1). The information is cross-sectional in nature, with no follow-up. It is worth mentioning that the only benefits considered in this study are elderly adult pensions. Other contributory benefits managed by ANSES, such as widow/widower pensions and non-contributory pension benefits (i.e., veterans of the Malvinas war, poor mothers with seven or more children, etc.) were not taken into account.

\section{Results}

\subsection{Decomposition of inequality levels}

Table 2 shows the results of Theil's decomposition for different pensioner groups. Benefits from provincial systems (4\% of the total) are higher on average than national benefits. At the same time, the Theil index (and the standardized Theil index) indicates that pension distribution is more equal in the latter group of pensions. ${ }^{19}$ However, the mean pension difference between groups does not account for most of the dispersion. As can be seen, the origin of the benefit (province or nation) accounts for $11 \%$ of total pension inequality.

Benefits from the scheme prior to the 1994 reform account for $19 \%$ of total pensions. The average pension is $10 \%$ higher in this group while the Theil value is almost $60 \%$ higher. Nevertheless, this reform plays a marginal role in explaining pension inequality compared to the other factors. Only $1 \%$ of the inequality is due to differences in the average pension, and this percentage is $2 \%$ when excluding moratorium pensions.

Because there is a relationship between wages and pensions, analyzing pension distribution by gender provides some information on the

18. Previous empirical studies on the Argentinean contributory pension system use different permanent household surveys conducted by the National Institute of Statistics and Censuses (INDEC) (see, for example, Rofman et al., 2008, Alejo et al. 2007 and Arza, 2006). In addition to permanent household surveys, another set of papers more closely related to the labor aspect of SIPA use data from a sample of workers collected by the Federal Administration of Public Revenues (Administración Federal de Ingresos Publicos, or AFIP), the National Institute of Social Security Resources (Instituto Nacional de los Recursos de la Seguridad Social, or INARSS) and ANSES (see SSSb, 2003). The only study that uses ANSES data from the entire population of beneficiaries is Giuri and Martinez (2001), but they work with aggregate information rather than microdata.

19. The standardized Theil index ensures that the measure of inequality is independent of the number of observations. 
Table 2. Theil decompositions by group, April 2009

\begin{tabular}{|c|c|c|c|c|c|c|}
\hline Description & & $\mathbf{N}$ & $\%$ & $\begin{array}{c}\text { Average real } \\
\text { pension }\end{array}$ & Theil & Theil std. \\
\hline $\begin{array}{l}\text { Provincial systems } \\
\text { National system }\end{array}$ & $\begin{array}{l}T W \\
T B\end{array}$ & $\begin{array}{c}154,195 \\
3,846,149 \\
89 \% \\
11 \%\end{array}$ & $\begin{array}{c}4 \\
96\end{array}$ & $\begin{array}{c}1,789 \\
947\end{array}$ & $\begin{array}{l}0.188 \\
0.086\end{array}$ & $\begin{array}{l}0.157 \\
0.057\end{array}$ \\
\hline $\begin{array}{l}\text { Before SIJP } \\
\text { After SIJP }\end{array}$ & $\begin{array}{l}T W \\
T B\end{array}$ & $\begin{array}{c}775,821 \\
3,224,523 \\
99 \% \\
1 \%\end{array}$ & $\begin{array}{l}19 \\
81\end{array}$ & $\begin{array}{c}1,059 \\
960\end{array}$ & $\begin{array}{l}0.135 \\
0.095\end{array}$ & $\begin{array}{l}0.099 \\
0.063\end{array}$ \\
\hline \multicolumn{7}{|c|}{ Excluding moratorium pensions } \\
\hline $\begin{array}{l}\text { Before SIJP } \\
\text { After SIJP }\end{array}$ & $\begin{array}{l}T W \\
T B\end{array}$ & $\begin{array}{c}775,820 \\
1,139,833 \\
98 \% \\
2 \%\end{array}$ & $\begin{array}{l}40 \\
60\end{array}$ & $\begin{array}{l}1,059 \\
1,274\end{array}$ & $\begin{array}{l}0.135 \\
0.178\end{array}$ & $\begin{array}{l}0.099 \\
0.128\end{array}$ \\
\hline $\begin{array}{l}\text { Female } \\
\text { Male }\end{array}$ & $\begin{array}{l}T W \\
T B\end{array}$ & $\begin{array}{c}2,442,945 \\
1,525,477 \\
91 \% \\
9 \%\end{array}$ & $\begin{array}{l}62 \\
38\end{array}$ & $\begin{array}{l}872 \\
909\end{array}$ & $\begin{array}{l}0.046 \\
0.158\end{array}$ & $\begin{array}{l}0.031 \\
0.111\end{array}$ \\
\hline $\begin{array}{l}\text { Moratorium } \\
\text { Non-moratorium }\end{array}$ & $\begin{array}{l}T W \\
T B\end{array}$ & $\begin{array}{c}2,084,691 \\
1,915,653 \\
83 \% \\
17 \%\end{array}$ & $\begin{array}{l}52 \\
48\end{array}$ & $\begin{array}{c}789 \\
1,187\end{array}$ & $\begin{array}{l}0.002 \\
0.167\end{array}$ & $\begin{array}{l}0.002 \\
0.115\end{array}$ \\
\hline $\begin{array}{l}\text { Special schemes } \\
\text { General scheme }\end{array}$ & $\begin{array}{l}T W \\
T B\end{array}$ & $\begin{array}{c}56,950 \\
3,943,394 \\
89 \% \\
11 \%\end{array}$ & $\begin{array}{c}1 \\
99\end{array}$ & $\begin{array}{c}1,639 \\
634\end{array}$ & $\begin{array}{l}0.169 \\
0.091\end{array}$ & $\begin{array}{l}0.154 \\
0.060\end{array}$ \\
\hline $\begin{array}{l}\text { Minimum pension } \\
\text { Non-minimum pension }\end{array}$ & $\begin{array}{l}T W \\
T B\end{array}$ & $\begin{array}{c}2,901,989 \\
1,098,355 \\
55 \% \\
45 \%\end{array}$ & $\begin{array}{l}73 \\
27\end{array}$ & $\begin{array}{c}771 \\
1,544\end{array}$ & $\begin{array}{l}0.000 \\
0.159\end{array}$ & $\begin{array}{l}0.000 \\
0.114\end{array}$ \\
\hline \multicolumn{7}{|c|}{ Excluding moratorium pensions } \\
\hline $\begin{array}{l}\text { Minimum pension } \\
\text { Non-minimum pension }\end{array}$ & $\begin{array}{l}T W \\
T B\end{array}$ & $\begin{array}{c}956,128 \\
959,525 \\
63 \% \\
37 \%\end{array}$ & $\begin{array}{l}50 \\
50\end{array}$ & $\begin{array}{c}771 \\
1,617\end{array}$ & $\begin{array}{l}0.002 \\
0.166\end{array}$ & $\begin{array}{l}0.001 \\
0.120\end{array}$ \\
\hline $\begin{array}{l}\text { Former AFJP system } \\
\text { PAYG system }\end{array}$ & $\begin{array}{l}T W \\
T B\end{array}$ & $\begin{array}{c}281,416 \\
3,718,928 \\
93 \% \\
7 \%\end{array}$ & $\begin{array}{c}7 \\
93\end{array}$ & $\begin{array}{c}1,098 \\
978\end{array}$ & $\begin{array}{l}0.186 \\
0.103\end{array}$ & $\begin{array}{l}0.148 \\
0.068\end{array}$ \\
\hline
\end{tabular}

Source: Author`s calclulations based on ANSES data for April 2009. Average real pensions are expressed in Argentine pesos of April 2009. 
differences in the working histories of female and male workers. As can been seen, retiree gender accounts for $9 \%$ of total inequality, $62 \%$ of total pensions corresponds to women, and these pensions are not only lower than those of men but less dispersed, which means that the working income considered in pension determination was more equally distributed for women.

On the contrary, the moratorium program has a more significant effect on the characterization of the pension distribution. These benefits account for $52 \%$ of the total benefits with an average pension of ARS 788.52, which is very close to the minimum legal pension of that period (ARS 770.96). Although the dispersion within each group (moratorium and non-moratorium benefits) accounts for most of the observed inequality, the program makes a significant contribution to total pension inequality (17\%).

Table 2 also shows that the benefits of special schemes account for $1 \%$ of total pensions. Both the average pension and the standardized Theil value of this group are about $150 \%$ higher than those of the general regime. Between-group inequality accounts for $11 \%$ of the total pension dispersion, which implies that the difference between the mean pensions of both groups is lower than the differences within each scheme.

Minimum pensions represent $73 \%$ of the total benefits and almost $50 \%$ of the pension inequality is accounted for by the difference between minimum and non-minimum pensions. This indicates that the pension indexation rules implemented during the period, together with the relative increase of new pensioners who entered the system with low incomes, had a significant impact on the pension distribution. As the vast majority of the moratorium benefits were minimum pensions, we excluded those benefits in an attempt to isolate the indexation effect. As can be seen, $37 \%$ of the decrease in total inequality is attributable to the gap between minimum and non-minimum pensions.

In sum, the implementation of the moratorium scheme together with all the measures that bring the minimum and non-minimum pension groups closer are the most important factors that account for the inequality observed in 2009. ${ }^{20}$ Nevertheless, the relevance of each factor to explaining the inequality depends on the period under consideration.

20. It is worth pointing out that although these measures are closely linked as almost all the moratorium benefits are minimum pensions, they are not the same because pension indexation is independent of the type of law giving rise to the benefit. 
For example, the importance of the implementation of Law 24,241 to pension inequality increased until 1998, with between-group effects rising from $2.5 \%$ to nearly $10 \%$. Since then, the relevance of the new law in accounting for the evolution of pension inequality has been declining. This factor represented $8.8 \%$ of the total dispersion in 2003, just $1.2 \%$ in 2008 and $0.8 \%$ in 2009 . Table A 2 of the appendix shows the Theil decomposition over the 1995-2008 period.

\subsection{Components of the change in pension inequality}

The JMP framework is used to estimate the contribution of both observed and unobserved quantities and prices to the observed change in pension inequality. To perform the technique described in the previous section, we estimate the following regressions by ordinary least squares (OLS): ${ }^{21}$

For 1996 and 2003:

$$
\begin{aligned}
\log (\text { pension })_{i t} & =\alpha_{t}+\beta_{1 t} \text { male }_{i t}+\beta_{2 t} \text { provincial }_{i t} \\
& +\beta_{3 t} \text { beforeSIJP }_{i t}+\beta_{4 t} \text { minimum }_{i t}+\mu_{i t}
\end{aligned}
$$

For 2006 and 2009:

$$
\begin{aligned}
\log \left(\text { pension }_{i t}=\right. & \alpha_{t}+\beta_{1 t} \text { male }_{i t}+\beta_{2 t} \text { provincial }_{i t} \\
& +\beta_{3 t} \text { beforeSIJP }_{i t}+\beta_{4 t} \text { min imu } m_{i t} \\
& +\beta_{5 t} \text { moratorium }+\beta_{6 t} \text { special }+\mu_{i t}
\end{aligned}
$$

The table below quantifies the contribution of observed quantities and prices and of unobservables (i.e., the within-group component) to the standard deviation increase in the 1996-2003 period (from 0.615 to 0.642 , see Table 1 ), and to the pension dispersion decrease in the 2006-2009 period (from 0.430 to 0.409 , see Table 1 ). The significant information shown in Table 3 is the difference in explanatory power for inequality above and below the mean.

Over the 1996-2003 period, the positive sign of the 90th and 10th percentiles' differential indicates an increase in pension inequality. The differential is higher in the upper part of the distribution. For those 
Table 3. Observed and unobserved components of changes in inequality

\begin{tabular}{|c|c|c|c|c|}
\hline $\begin{array}{l}\text { Percentile } \\
\text { differential }\end{array}$ & $\begin{array}{c}\text { Total } \\
\text { change }\end{array}$ & $\begin{array}{l}\text { Observed } \\
\text { quantities }\end{array}$ & $\begin{array}{c}\text { Observed } \\
\text { prices }\end{array}$ & $\begin{array}{l}\text { Unobserved } \\
\text { prices and quantities }\end{array}$ \\
\hline \multicolumn{5}{|c|}{ 1996-2003 } \\
\hline $90-10$ & 0.098 & 0.102 & 0.027 & -0.032 \\
\hline $90-50$ & 0.081 & 0.193 & 0.022 & -0.134 \\
\hline $50-10$ & 0.016 & -0.091 & 0.005 & 0.102 \\
\hline \multicolumn{5}{|c|}{ 2006-2009 } \\
\hline $90-10$ & -0.349 & -0.105 & 0.027 & -0.270 \\
\hline $90-50$ & -0.349 & -0.105 & 0.015 & -0.258 \\
\hline $50-10$ & 0.000 & 0.000 & 0.012 & -0.012 \\
\hline
\end{tabular}

pensions, changes in observed quantities exerted the most significant effect on the increase in inequality. Table A4 of the appendix shows that this result could be explained by the increase in the relative size of post-SIJP and provincial pensions in 2003, since these benefits presented higher average pensions and less dispersion than existing benefits at that time. For pensions below the median, the observed quantities and the unobserved component were almost equally important (but with opposite signs) in the change in inequality. The negative sign of the observed characteristic component could be explained mainly by the relative increase in the number of female retirees. By 2003, this group presented lower and less dispersed pensions than those of male retirees, reducing total pension dispersion (see Table A4 of the appendix). Concerning the effect of the unobserved component, one possible explanation discussed below may be related to the dispersion of wages. In sum, from 1996 to 2003 pension distribution became more unequal and the change in the dispersion of pensions seems to be much more understandable in terms of the change in the composition of the beneficiaries (observed characteristics) rather than in terms of changes in the prices of those characteristics (i.e., changes in pension amounts).

In the second period, the unobserved component was the greatest contributor to the total decrease in inequality. As shown, the residual component accounts for the vast majority of the decrease in inequality for pensions above the median while the second factor 
in importance is the quantities component. The latter component reflects the increase in the number of moratorium and minimum pension benefits resulting from the moratorium plan. In fact, because of the incorporation of moratorium benefits, in $2006,50 \%$ of pensions were minimum pensions and in 2009 that percentage increased to $70 \%$. As both groups presented less dispersion and lower pensions than average benefits in 2009, their relative increase in total benefits favors a more equal distribution of pensions (see Table A4 of the appendix). For pensions below the median, the positive change in the return of the observed characteristics and the negative change in the unobserved component (both with a similar absolute value magnitude) account for the absence of change in inequality, since the quantities component is null. As stated above, the negative sign of the residual is probably linked to the dispersion of the wages used to determine the pension amount.

In sum, over the entire period changes in the observed characteristics of pensions were more relevant in accounting for changes in inequality than changes in the return of those characteristics. Besides, the unobserved factors determining pensions played a significant role in accounting for the more equal distribution over the 2006-2009 period, and a secondary role in accounting for the increase in inequality over the 1996-2003 period.

One factor that is linked to pension amounts are retirees' salaries, or more precisely, salaries subject to contributions. The relationship between labor market factors and pensions depends on the formula established by the different pension systems. For pensions under Law 18,037 of 1967 (for wage earners), the benefit was established between $70 \%$ and $82 \%$ of salary upon retirement, depending on the total number of years of contributions to the system. In the case of self-employed workers (Law 18,038 of 1968), pensions were calculated as $100 \%$ of estimated average income. For provincial benefits transferred to the national system, the pension amount was generally established as $82 \%$ of the salary, depending on the province. ${ }^{22}$ Benefits under the special regimes are calculated between $82 \%$ and $85 \%$ of the salary.

22. For details, see provincial laws 4,094/4,620 (Catamarca), 2,432/2,502 (Río Negro), 4,042 (Jujuy), 6,719 (Salta), 4,266/6,561 (San Juan), 6,446 (Tucumán), 3,794 (Mendoza), 3,900 (San Luis), 4.558 (Santiago del Estero), 5,451 (La Rioja), as well as ordinances 27,897 and 40,594 of the Municipality of Buenos Aires and ordinances 296/78 and 224/84 of the Municipality of Tucumán. 
Finally, as mentioned in Section 2, the pension benefit amount under Law 24,241 (SIPA) is defined as the sum of a flat component (PBU), which is identical for all workers regardless of their contributions, plus a component that depends on salary $(\mathrm{PC}+\mathrm{PAP})$, which is defined as $1.5 \%$ of the average salary over the 10 years before retirement, multiplied by the number of years the worker has contributed to the pension system. ${ }^{23}$ This formula establishes a relationship between salary and pension. For example, for workers with 30 years of contributions, the contributory pillars (PC + PAP) of the benefit will account for $45 \%$ of the average reference salary. This sum will not exceed $52.5 \%$ of the workers' reference wage (i.e., $1.5 \%$ multiplied by 35 years). ${ }^{24}$

Hence, if the dispersion of salaries subject to contributions is similar to pension dispersion, the residuals of the JMP methodology regressions could be reflecting the impact of labor income on the pension distribution.

As the database does not include retirees' salaries, we analyze the unobserved factor of equations (8) and (9) together with the distribution of the unrestricted pension amount (hereafter "pure pension") as a proxy of labor income. The pure pension is defined as the sum of $\mathrm{PBU}+\mathrm{PC}+\mathrm{PAP}$ for benefits under Law 24,241 (general regime) or the legal percentage of salaries for other benefits (laws 18,037, 18,038 and special regimes). The distribution of pure pensions differs from that of real benefits since they do not consider either the minimum pension restriction or the maximum pension cap. ${ }^{25}$

Because the database includes the pure pension amounts at the time retirees enter the system and these remain fixed over time, the pure pension distribution of the stock of beneficiaries at any time will also reflect the cohort effect (i.e., variations due to differences at the time pensioners enter the system). So, in the analysis below we have only considered the pure pensions of new pensioners who enter the system each year.

It is worth mentioning that in order to receive a pension, retirees of the moratorium program were required to be registered as self-employed

23. From April 1996 to April 2009, the PBU increased 92\% in nominal terms (from ARS 190 to ARS 364.1). 24. Law 24,241, Articles 24 and 30.

25. It should be noted that consideration of the taxable wage in the pension formula does not mean that the resulting pension amount is equal to the maximum legal pension. 
Table 4. Changes in inequality for log proxied salaries and $\log$ pension residuals

\begin{tabular}{|ccc|}
\hline Percentile differential & Log pure pensions & Log pension residuals \\
\hline & $\mathbf{1 9 9 6 - 2 0 0 3}$ & \\
\hline $90-10$ & -0.054 & -0.032 \\
$90-50$ & -0.075 & -0.134 \\
$50-10$ & 0.022 & 0.102 \\
\hline & $\mathbf{2 0 0 6 - 2 0 0 9}$ & \\
\hline $90-10$ & -0.217 & -0.270 \\
\hline $90-50$ & -0.066 & -0.258 \\
$50-10$ & -0.150 & -0.012 \\
\hline Source: Author`s calculations based on ANSES data for April of each year. & \\
\hline
\end{tabular}

workers with the Federal Administration of Public Revenues (AFIP). Nearly all retirees were registered in the category with the lowest estimated income, which was used as reference when determining the pension amount. ${ }^{26}$ As the vast majority of the program beneficiaries entered the system in 2007, pure pension dispersion fell sharply due to this method. Therefore, to minimize distortions in the relationship between pensions and wages, we have excluded the benefits from the moratorium program.

Table 4 reveals an interesting finding: In all cases, the sign of the log pure pension differential is the same as that of the log real pension differential. However, the magnitude of the change differs. Apart from the fact that moratorium benefits have been excluded, this occurs because while pure pensions are linked to salaries subject to contributions, they include the flat PBU component. ${ }^{27}$ In addition, we have considered the pure pension dispersion of new retirees entering the system in April of each year, while the pension residuals are estimated for the stock of beneficiaries in April of each year.

26. For the lowest category of self-employed workers, a monthly income of ARS 400 is assumed for those years. In 2007, the average salary of workers registered as both dependent and independent (excluding moratorium beneficiaries) amounted to ARS 855.12.

27. However, the effect of the exclusion of moratorium benefits should not be significant since the majority of pensioners under Law 25,994 entered the system in 2007 and in 2009 this plan was closed (only new pensions under Law 24,476 were registered). 
This simple exercise shows that the effect of the taxable labor income dispersion on total pension distribution could be the one captured in the unobserved component of the pension equation. ${ }^{28}$ Both in the first and second period, the differential of the residuals' 90th and 10th percentiles is negative, but the magnitude is much higher in the 2006-2009 period. This result could suggest not only a greater share of the PBU component in total pension amount, but also that the indexation of the maximum taxable income has been lower than wage increases. In fact, from April 2003 to April 2009 mean gross wages increased $94 \%$ (AFIP, 2012) while the average taxable wage (remuneración imponible promedio de los trabajadores estables, RIPTE) increased $86 \%$ (MTESS, 2012) indicating that indexation of the salary cap plays a significant role in characterizing pension distribution. ${ }^{29}$

\section{Conclusions}

During the last two decades, the Argentinean pension system has undergone substantial structural reforms. In 1994, as part of the wave of deregulation that spread throughout the economic sphere, the system became a mixed scheme combining defined benefit and defined contribution components, as well as private and public management. However, the unfavorable evolution of the labor market during the 1990s and 2000s (rising unemployment and informality) caused the model to fail. In an attempt to solve the negative results of the SIJP scheme, especially low and decreasing pension coverage and loss of purchasing power among pensioners, since 2003 national authorities have implemented several reforms and, in 2008, the retirement pension system became a public PAYG scheme once again.

At the same time, we identify changes in pension distribution during the 1993-2006 period. Two different periods can be distinguished: the first starts with SIJP implementation in 1994 and continues to 2003, while the second one is from 2003 to 2009. The first period is characterized by a slight increase in pension inequality, whereas in the last period pension distribution was more equal. Over the 1996-2003

28. It is important to distinguish between taxable and gross (before-tax) labor income because the latter, unlike residuals, became more unequal over the 1996-2003 period (see Table 1).

29. Over the first period (1996-2003), mean gross wages decreased almost 9\% while RIPTE decreased $4 \%$ (MTESS, 2012). In this case, the potential role of the salary cap in pension distribution in 1996 could have lost strength in the context of decreasing salaries in 2003. 
period the incorporation of pensions under SIJP rules, as well as the transfer of provincial benefits to the national system, appear to play an important role in increased inequality. This effect has more to do with the rising share of these retiree groups (with less dispersed pensions but a much higher income relative to the overall mean pension) than with changes in pension amounts. Additionally, the relative increase of female retirees also plays a significant role in changes in distribution as a smoothing factor of inequality. From 2003 onward, the increase in the share of minimum pensions, together with the implementation of the moratorium program, appear to be the most relevant factors in accounting for the more equal distribution.

The JMP micro-decomposition also shows that the unobserved factors (i.e., factors included in the error term of the pension equation) play a significant role in characterizing the observed changes in pension distribution, mainly in the second period. One factor that is linked to pension amounts is retirees' salaries, or more precisely, salaries subject to contributions. Using data on unrestricted pension amounts (pure pension) as a proxy of taxable labor income, we have found that there is a direct relationship between changes in the residuals of pension inequality regressions and pure pensions. The negative sign of the difference between the 90th and 10th percentiles could suggest not only a greater share of the PBU component in total pension amount, but also that the salary cap plays a significant role in pension inequality.

These findings provide some direction for future research. One extension of this paper could be a detailed study of the effect of each component of pension distribution using a technique that enables aggregation of the different components of the decomposition, such as a combination of quantile regression and JMP decomposition. Another interesting issue that emerges from this paper is the analysis of taxable salaries and pension caps and the implications in terms of inequality. Finally, the research topics suggested, together with the changes in pension inequality documented here, could guide future research to support policy recommendations for design of the PAYG scheme. 


\section{REFERENCES}

Administración Federal de Ingresos Públicos (AFIP) (2012), Anuario Estadísticas Tributarias (2003, 2006 and 2009) [Tax Statistics Yearbook], Buenos Aires. Retrieved in October 2012 from http://www.afip.gob.ar/estudios/anuario.asp.

Administración Federal de Ingresos Públicos (AFIP) (2008), SIJP. Informe Gerencial [SIJP: Management Report], Buenos Aires.

Administración Nacional de la Seguridad Social (ANSES) (2009), Fondo de Garantía de Sustentabilidad. Comisión Bicameral-Congreso de la Nación [Sustainability Guarantee Fund: Bicameral Commission, National Congress]. Presentation. Retrieved in June 2011 from http://www.anses.gob.ar/FGS/ archivos/Presentacion-BossioAgosto.pdf.

Alejo, J., L. Gasparini, F. Haimovich, S. Olivieri, and L. Tornarolli (2007), "Poverty among the elderly in Latin America and the Caribbean." Contribution to the World Economic and Social Survey 2007, Development in an Ageing World, Working Paper 55, CEDLAS.

Arza, C. (2008), "Pension reform in Latin America: Distributional principles, inequalities and alternative policy options," Journal of Latin American Studies, $\mathbf{4 0}(1)$.

Arza, C. (2006), "Distributional impacts of pension policy in Argentina: Winners and losers within and across generations," International Social Security Review, 59(3).

Bourguignon F. (1979), "Decomposable income inequality measures," Econometrica 47: $901-20$.

Bourguignon, F., F. Ferreira, and N. Lustig (2005), The Microeconometrics of Income Distribution Dynamics. New York: Oxford University Press.

Cowell, F. (1980), "On the structure of additive inequality measures," Review of Economic Studies 47(3): 521-31.

Cruces, G. and L. Gasparini (2009), "Desigualdad en Argentina. Una revisión de la evidencia empírica" [Inequality in Argentina: A review of the empirical evidence], Desarrollo Económico 49(193): 3-29.

D'Elia, V., A. Calabria, A. Calero, J. Gaiada, and S. Rottenschweiler (2010), "Análisis de la Cobertura Previsional del SIPA: Protección, Inclusión e Igualdad" [Analysis of SIPA pension coverage: Protection, inclusion and equality], Serie Estudios Especiales, ANSES, Buenos Aires.

Gasparini, L. (1999), "Un análisis de la distribución del ingreso en Argentina sobre la base de descomposiciones" [An analysis of income distribution in Argentina on the basis of decompositions], in La Distribución del ingreso en Argentina, FIEL, Buenos Aires.

Gasparini, L., M. Marchionni, and W. Sosa Escudero (2000), "La distribución del ingreso en Argentina y en la provincia de Buenos Aires" [Income distribution in Argentina and Buenos Aires Province]. Cuadernos de Economía 49, Ministerio de Economía de la Provincia de Buenos Aires.

Gasparini, L. and W. Sosa Escudero (2001), "Assessing aggregate welfare: Growth and inequality in Argentina," Cuadernos de Economía, 38(113): 49-71. 
Giuri, M. and E. Martinez (2001), "Un análisis de la desigualdad en el sistema previsional de reparto" [An analysis of inequality in the distribution pension system]. Presented at the 34th International Public Finance Conference, Universidad Nacional de Córdoba.

Groisman, F. (2008), "Distributive effects during the expansionary phase in Argentina (2002-2007)", CEPAL Review 96: 203-20.

INDEC (2011), Consumer Price Index Series. Retrieved in June 2011 from http:// www.indec.gov.ar/.

Juhn, C., K. Murphy, and B. Pierce (1993), "Wage inequality and the rise in returns to skill," Journal of Political Economy 101(3): 410-42.

Ministerio de Trabajo, Empleo y Seguridad Social (MTESS) (2012), "Remuneración imponible promedio de los trabajadores estables (RIPTE)" [Average taxable income of stable workers], Buenos Aires. Retrieved in October 2012 from http://www.trabajo.gov.ar/downloads/seguridadSoc/INF_RIPTE.pdf.

Oaxaca, R. (1973), "Male-female wage differentials in urban labor markets," International Economic Review, 14(3): 693-709.

Rofman, R. (1995), "Effects of social security on lifetime income distribution in Argentina," PSP Discussion Paper Series No. 17364, World Bank.

Rofman, R., L. Lucchetti, and G. Ourens (2008), "Pension systems in Latin America: Concepts and measurement of concepts," World Bank PSP Discussion Paper Series No. 0616.

Secretaría de la Seguridad Social (SSSa) (2003), Libro Blanco de la Seguridad Social [Social Security White Paper], Ministry of Labor and Social Security, Buenos Aires.

Secretaría de la Seguridad Social (SSSb) (2003), Historias Laborales en la Seguridad Social [Labor Histories in Social Security], Ministry of Labor and Social Security, Buenos Aires.

Socio-Economic Database for Latin America and the Caribbean) (SEDLAC) (2012). "Gini coefficient for the distribution among individuals of different household income variables." Retrieved in September 2012 from http:// sedlac.econo.unlp.edu.ar/esp/estadisticas-detalle.php?idE $=18$.

Shorrocks, A. (1984), "Inequality decomposition by population subgroups," Econometrica 52(6): 1369-86.

Tsakloglou, P. (1993), "Aspects of inequality in Greece: Measurement, decomposition and intertemporal change: 1974, 1982," Journal of Development Economics, 40(1): 53-74.

World Bank (1994), Averting the Old Age Crisis: Policies to Protect the Old and Promote Growth, Oxford. 


\section{APPENDIX A}

Table A1. Pension formula, 1994

\begin{tabular}{|c|c|c|c|}
\hline \multirow{2}{*}{ Benefit } & \multirow{2}{*}{ Formula } & \multicolumn{2}{|c|}{ Pensioners } \\
\hline & & PAYG system & Funded system \\
\hline $\begin{array}{l}\text { Flat-rate benefit } \\
\text { (prestación básica } \\
\text { universal, PBU) }\end{array}$ & $\begin{array}{l}\text { Per Law } 24,241 \text {. the PBU } \\
\text { amounts to } 2.5 \text { times the average } \\
\text { employee's contributions (aporte } \\
\text { medio previsional obligatorio, } \\
\text { AMPO). However, Decree } \\
833 / 97 \text { changed the PBU to } 2.5 \\
\text { times the módulo previsional, } \\
\text { MOPRE, which was set at } \$ 80 \text { by } \\
\text { Resolution } 661 / 97 \text { of the Ministry } \\
\text { of Labor. Its value was adjusted } \\
\text { on an ad hoc basis until Law } \\
26,417 \text { on indexation of benefits. }\end{array}$ & Yes & Yes \\
\hline $\begin{array}{l}\text { Earning-related } \\
\text { benefit (prestación } \\
\text { compensatoria, } \\
\text { PC) }\end{array}$ & $\begin{array}{l}P C=\frac{1}{10} \cdot \sum_{x=R-10}^{R-1}\left(w_{x} \cdot i\right) \cdot 0.015 \cdot y_{\text {before July } 94} \\
\text { Where } w \text { is the annual salary, } x \text { is } \\
\text { the worker's age, } i \text { is the annual } \\
\text { indexation coefficient, } y \text { is the } \\
\text { number of years of contribution } \\
\text { before July } 1994 \text { and } R \text { is the } \\
\text { retirement age. }\end{array}$ & Yes & Yes \\
\hline $\begin{array}{l}\text { Prestación } \\
\text { Adicional por } \\
\text { Permanencia } \\
(\text { PAP) }\end{array}$ & $\begin{array}{l}\text { 1994-2007 } \\
P A P=\frac{1}{10} \cdot \sum_{x=R-10}^{R-1}\left(w_{x} \cdot i\right) \cdot 0.0075 \cdot y_{\text {after July } 94} \\
\text { since } 2007 \\
P A P=\frac{1}{10} \cdot \sum_{x=R-10}^{R-1}\left(w_{x} \cdot i\right) \cdot 0.015 \cdot y_{\text {after } J u l y 94} \\
\text { Where } w \text { is the annual salary, } x \text { is } \\
\text { the worker's age, } i \text { is the annual } \\
\text { indexation coefficient, } y \text { is the } \\
\text { number of years of contribution } \\
\text { after July } 1994 \text { and } R \text { is the } \\
\text { retirement age. }\end{array}$ & Yes & No \\
\hline $\begin{array}{l}\text { Jubilación } \\
\text { Ordinaria (JO) }\end{array}$ & $\begin{array}{l}J O=\frac{1}{a c} \cdot \sum_{x=1994-B}^{R-1} w_{x} \cdot(c-e) \cdot(1+r)^{R-x} \\
\text { Where } c \text { is the contribution } \\
\text { rate, } e \text { are the administrative } \\
\text { and insurance costs, } r \text { is the } \\
\text { capital return, } a c \text { is the cost of } \\
\text { an annuity of } \$ 1, B \text { is the year of } \\
\text { worker birth, } x \text { is the worker's age } \\
\text { and } R \text { is the retirement age. }\end{array}$ & No & Yes \\
\hline
\end{tabular}




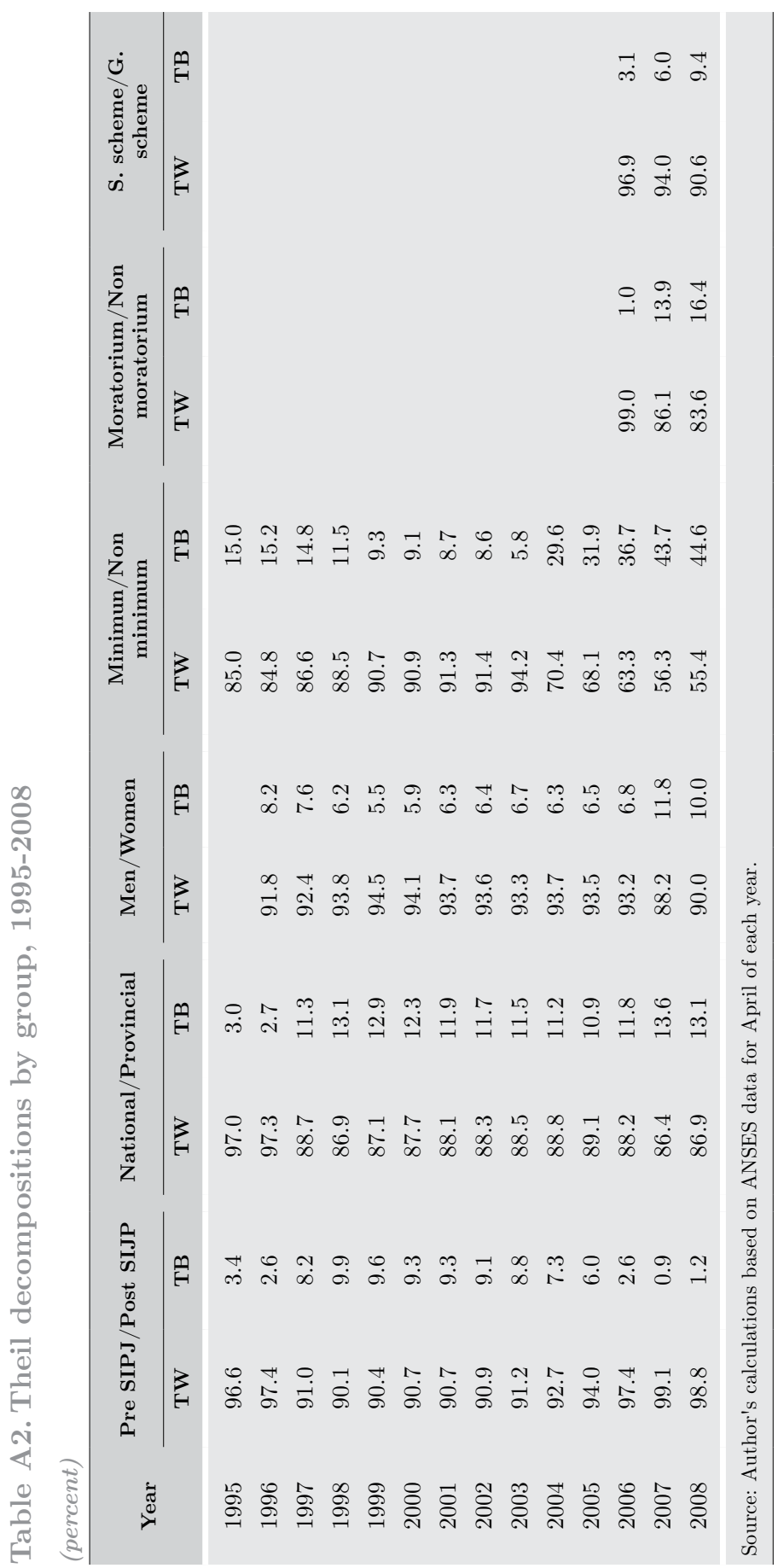


Figure A1.Change in log relative pension by decile, 1996-2003 and 2006-2009

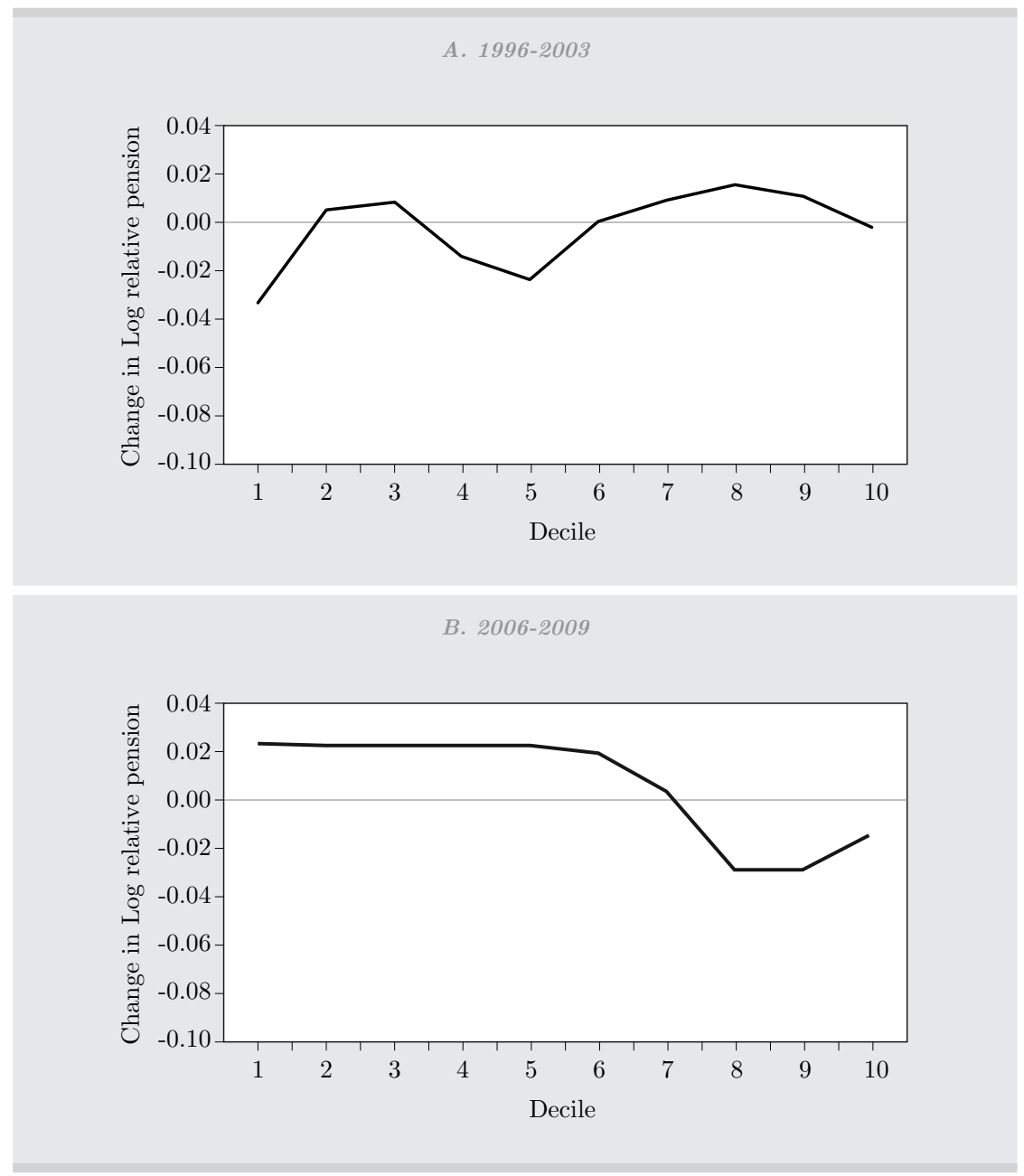

Source: Author's calculation based on ANSES data for April of each year. 


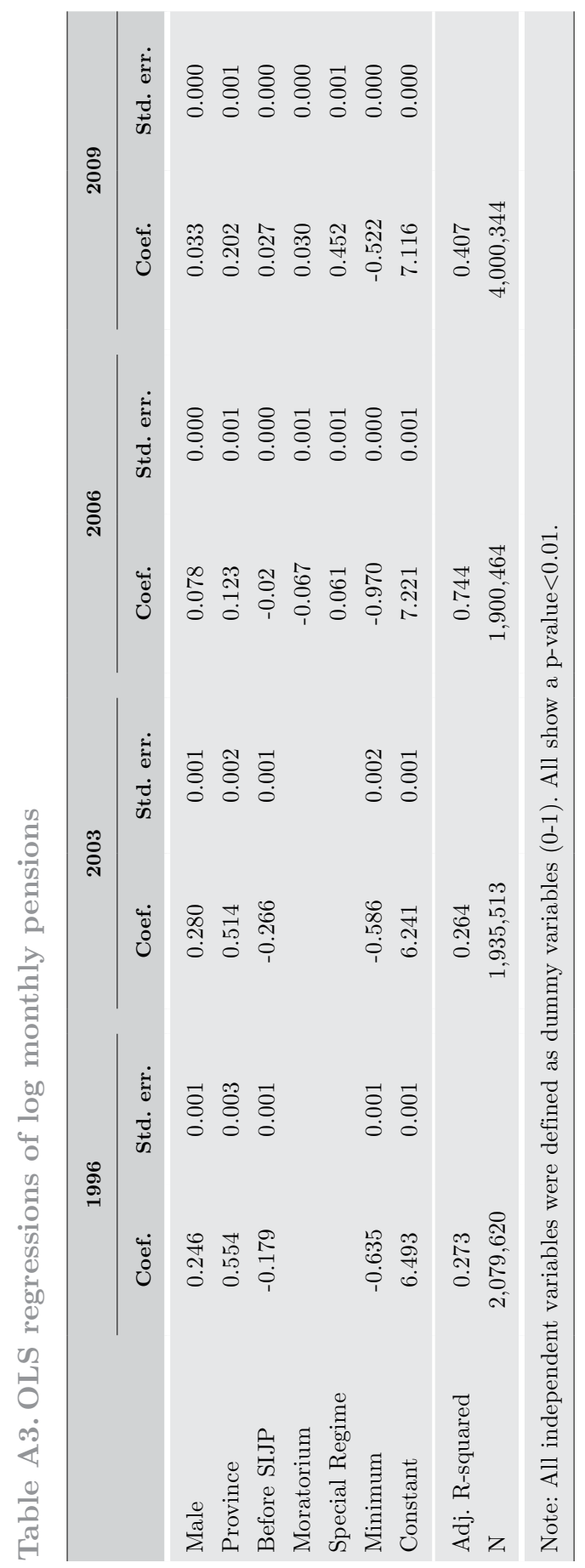




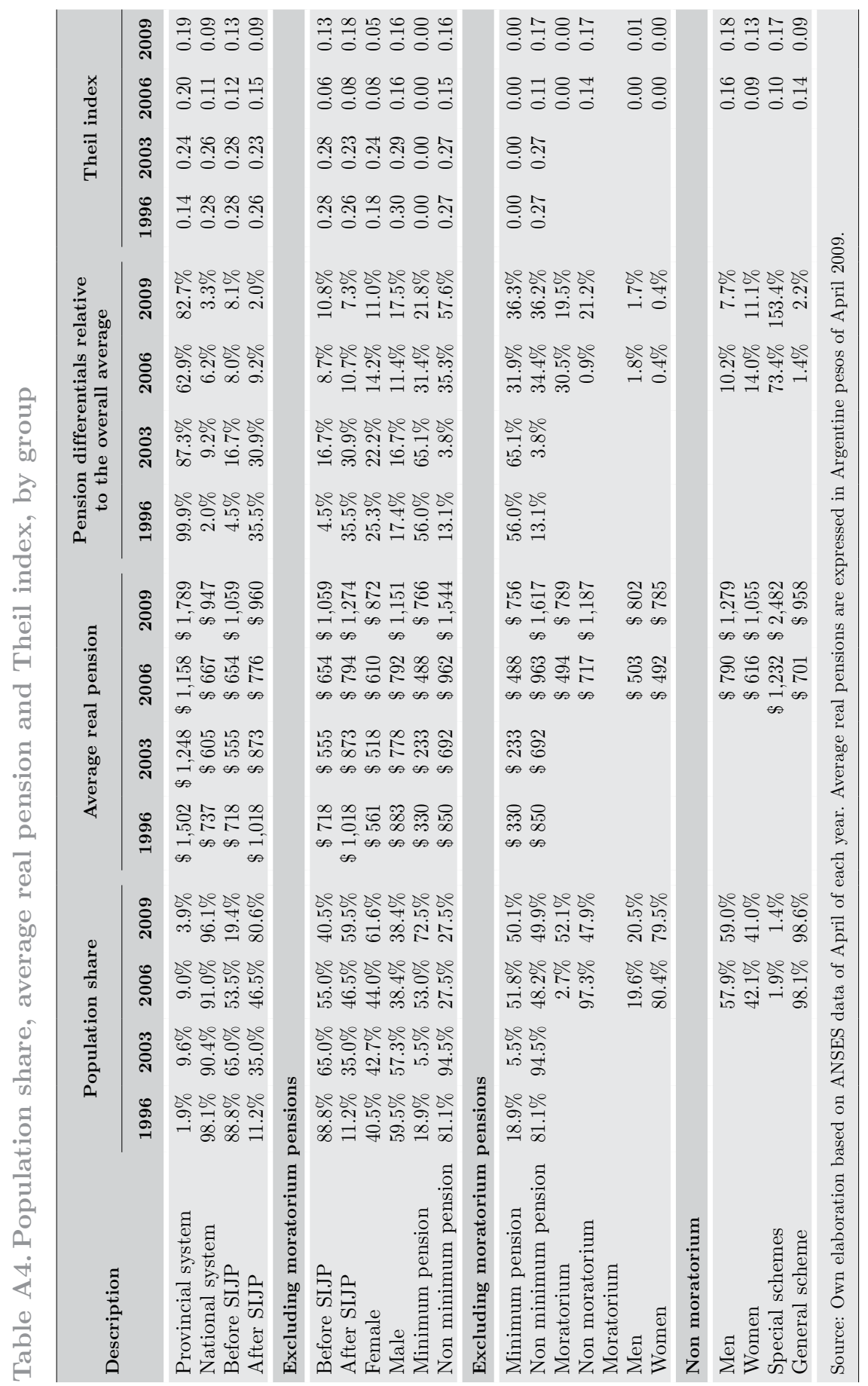


